\title{
Population structure of the common sole (Solea solea) in the Northeastern Atlantic and the Mediterranean Sea: revisiting the divide with EPIC markers
}

\author{
J. L. Rolland ${ }^{1}$, F. Bonhomme ${ }^{1}$, F. Lagardère ${ }^{2}$, M. Hassan ${ }^{1}$ and B. Guinand ${ }^{1, \text {, }}$
}

(1) Laboratoire Génome, Populations, Interactions, Adaptation, Université Montpellier II-IFREMER-CNRS UMR 5171, Station Méditerranéenne de l'Environnement Littoral, 1 Quai de la Daurade, 34200 Sète, France

(2) Centre de Recherche sur les Ecosystèmes Marins et Aquacoles de L'Houmeau (CREMA), CNRS-IFREMER, BP 5, 17137 L'Houmeau, France

*: Corresponding author : guinand@univ-montp2.fr

\begin{abstract}
:
Spatial and temporal population genetic structures of the common sole, Solea solea, were studied in Northeastern Atlantic and Mediterranean Sea populations, using three polymorphic exon-primed intron-crossing (EPIC) markers. Results demonstrated significant multilocus differentiation among Eastern Mediterranean and a group composed by Western Mediterranean and Atlantic populations $(\theta$ $=0.150, \mathrm{P}<0.001$ ), but also suggested unrecorded genetic differentiation of the Adriatic Sea population. No pattern of isolation-by-distance was recorded across the range covered by sampling, from the Kattegat to the Aegean Sea. Conversely to genetically structured Mediterranean populations, Atlantic populations ranging from Denmark to Portugal could be considered as representative of the same panmictic unit $(\theta=0.009$, not significant). Results further demonstrated stability of multilocus genetic structure among temporarily replicated cohort samples $[0+, 1+$, subadults] from several coastal and estuarine locations from Bay of Biscay, excepted for the amylase locus Am2B3-2 at one location (Pertuis d'Antioche). Despite coherence of such observed patterns of multilocus differentiation with previous allozymic surveys in sole, and with patterns generally obtained for other marine fish species, single-locus results from EPICs indicated divergent coalescence schemes supporting a complex response to ecology and history of sole's populations. Results stress the use of nuclear genes such as EPIC markers to investigate population structure, but also historical, demographic, and possibly selective processes in marine fishes.
\end{abstract}

Keywords: common sole, introns, genetic structure, marine fish. 


\section{Introduction}

Over the last two decades, studies of marine fish population genetic have accumulated, contributing to a better understanding of population structure and stock composition in the North Eastern Atlantic and the Mediterranean Sea (Borsa et al. 1997a; Bargelloni et al. 2003; Zardoya et al. 2004; and references therein). These studies questioned evolutionary mechanisms in the marine environment, the role of life-history traits (e.g. duration of the larval pelagic phase) in shaping patterns of genetic structure, and played a part in the improvement of guidelines for fish stocks exploitation. Phylogeographical studies demonstrated significant differentiation between the Atlantic and the Mediterranean among marine fish or invertebrates (review in, e.g. Borsa et al. 1997a). However, the geographical position of the transition between the two basins appeared to be different depending on the species considered. For instance a strong to moderate genetic divergence between the Atlantic and the Mediterranean Sea was reported in numerous fish species (e.g. sea bass: Dicentrarchus labrax, mackerel: Scomber scombrus, white anglerfish: Lophius piscatorius, and some Sparidae) whereas other species (e.g. chub mackerel: Scomber japonicus, black anglerfish: Lophius budegassa, other Sparidae, and Trachurus spp.) demonstrated no differentiation at all (see examples in e.g. Borsa et al. 1997a; Naciri et al. 1999; Bargelloni et al. 2003, 2005; Karaiskou et al. 2004; Zardoya et al. 2004; Charrier et al. 2006; and references therein). Moreover, it has been shown that the levels and patterns of genetic differentiation within each water body display marked differences. Atlantic shelf and North Sea populations were generally found broadly panmictic (e.g. Kotoulas et al. 1995; Hoarau et al. 2002; but see Hutchinson et al. 2001; Exadactylos et al. 2003), or reflecting patterns of isolation-bydistance (IBD) (e.g. Mariani et al. 2005; Gysels et al. 2004). On the other hand, nonshelf Atlantic populations (e.g. Nesbø et al. 2000; Hoarau et al. 2004), and Baltic Sea populations (e.g. Nielsen et al. 2003, 2004) were shown to be genetically differentiated from adjacent continental shelf Atlantic waters. Subtle local differentiation were observed to occur along Atlantic shorelines in some species (e.g. hake: Merluccius merluccius; Castillo et al. 2005), but due to limited sampling these studies were unable to clearly state whether this was due to a IBD pattern. Mediterranean populations of most investigated species were often found genetically differentiated, according to various models and reflecting a variety of demographic histories (e.g. Bahri-Sfar et al. 2000; Viñas et al. 2004; Magoulas et al. 2006). Most study published so far reported differentiation among the Western and Eastern Mediterranean basins of numerous invertebrate or vertebrate marine species (review in Borsa et al. 1997a), together with possible genetic distinctiveness of the Adriatic Sea (e.g. Borsa et al. 1997b; Tinti et al. 2002). Such patterns of genetic structure have been traditionally attributed to historical processes favouring vicariance, and to combined effects of contemporary gene flow modulated by ecological traits and hydrological features (e.g. Magoulas et al. 2006).

If such patterns of (phylo)geographic differentiation are then now wellestablished for numerous European marine fish species, most studies examining genetic differentiation of marine fish populations assumed temporal homogeneity of samples, and included sampling on just one occasion. This often translated in a "steady-state" picture of genetic structure, that was of very poor use for management. As populations fluctuate in terms of abundance, distribution, and recruitment, temporal heterogeneity is expected and should reflect in the inferred genetic population structure. Temporal changes in the genetic structure of marine population has been examined in some studies. For example, in a year (2001) with high inflow of North Sea waters into the Skagerrak, Knutsen et al. (2004) found that juvenile cod (Gadus morhua) caught along the Skagerrak coast are predominantly of North Sea origin, whereas in a year (2000) with low inflow juveniles appear to be of local origin. These findings indicate that offshore cod may influence coastal cod populations over large distances depending on the environment, then influence our perception of genetic structure and some management issues. Similar results have been described in herring (Clupea harengus) within the North Sea (Ruzzante et al. 2006). Conversely, only the use of temporarily replicated samples in eels (Anguilla anguilla) firmly proved the paradigm of panmixia reported for this species (Dannewitz et al. 2005), but also subtle temporal genetic differences across arrival waves (early vs late) of juveniles at a single site (Pujolar et al. 2006; Maes et al. 2006). Such kind of results were not only useful in terms of fishery management, but also for better understanding of mechanisms underlying temporal differentiation among cohorts at a single locale ('chaotic genetic patchiness' sensu Johnson and Black 1982), mainly including large variance in reproductive success that might shape temporal variation in the genetic composition of recruits ('sweepstake hypothesis', Hedgecock 1994; e.g. Chapman et al. 2002; Planes and Lenfant 2002; Pujolar et al. 2006), but also gene flow from different spawning populations with different allelic composition (e.g. Ruzzante et al. 1996), or potential selection on larval stages leading to differential mortality of genotypes before recruitment (Planes and Roman 2004). All three mechanisms might operate concurrently and are especially difficult to disentangle. In flatfish, temporal genetic differentiation was only assessed among different cohorts in plaice (Pleuronectes platessa). In this species, using 
microsatellite loci, Hoarau et al. (2005) reported local panmixia across cohorts (juveniles vs adults) at each sampled nursery in a given year (2002; i.e. indicating no or few variance in local reproductive success), together with change in levels of inbreeding in each sampled population over decades (possibly indicating change in effective population sizes that influenced genetic composition of recruits). One older allozyme study by Beardmore and Ward (1977) indicated relationships between gene diversity, genotypic composition and growth in plaice, suggesting selective processes.

The common sole, Solea solea, is a highly valued commercial fish in both Atlantic and Mediterranean Europe. It represents a major resource in the Bay of Biscay, where 1800 tons are harvested yearly (Léauté and Caill-Milly, 2003). However, since 1993 the spawning biomass of the Bay of Biscay stock has been undergoing a constant decline and it is currently at risk, with the lowest level of recruitment of the last 20 years recorded for the year class 1999 (Anonymous, 2003). Together with more holistic approaches (e.g. ecosystem-based fishery management), management regime needs to consider intraspecific genetic diversity to investigate both temporally and spatially patterns of genetic diversity within- and among populations together with population structure (Kenchington et al. 2003). In sole, previous population genetics studies have been carried out, using different kinds of genetic markers (allozymes: Kotoulas et al. 1995, Exadactylos et al. 1998, Cabral et al. 2003; RAPDs, Exadactylos et al. 2003; mtDNA: Guarniero et al. 2002). In the most extensive of these studies, Kotoulas et al. (1995), using allozymes, reported multilocus genetic differentiation between Mediterranean and Atlantic populations, as well as among eastern and western Mediterranean samples. This result was later supported by Guarniero et al. (2002). Kotoulas et al. (1995) also indicated weak IBD across Atlantic populations ranging from Denmark to Portugal, whereas more local and regional studies indicated absence of population structure (Exadactylos et al. 1998, Cabral et al. 2003). Such findings need to be investigated with other markers to infer more thoroughly spatial genetic structure. Furthermore in sole, to our knowledge, only one study investigated the temporal genetic differentiation at a local scale (Vilaine estuary in the Bay of Biscay; Kotoulas et al., 1995), reporting moderate allozymic differentiation among samples due to a negative trend between heterozygote deficiency and age in sole. As no other samples than the Vilaine samples where temporarily replicated in Kotoulas et al.'s (1995) study , the reality of temporal genetic differentiation in sole cannot be extended further.

In that context, the present study meant to reach two objectives: i) to revisit, using three nuclear exon-primed intron-crossing (EPIC) markers, the established patterns of genetic structure across the North Eastern Atlantic and the Mediterranean Sea; ii) to examine the temporal stability of population genetic structure at selected coastal locations in the Bay of Biscay.

\section{Materials and methods}

\section{Sample and data collection}

Twenty four Solea solea (L.) samples of sizes comprised between 23 and 70 individuals (total sample size, $N=749$ ), and collected between 2000 and 2002 in the Atlantic (along the shore of Portugal, Bay of Biscay, and English Channel) and the Mediterranean Sea were available to the present study (Fig. 1). A Danish sample originating from Kattegat at the junction of Baltic and North Sea was also studied. These samples were obtained from scientific cruises or commercial fishing operations, and covered not all, but most of the distribution area of the species on the continental shelf (Quéro et al. 1986). Details on sampling collection, sampling areas, and sampling dates are given in Table 1. Most populations of the Bay of Biscay were re-sampled up to three times on different sampling dates to investigate genetic differentiation over distinct cohorts (juveniles $[0+$, $1+]$, subadults) (Table 1). This point was scarcely investigated in previous genetic studies of sole (see Introduction). The Bay of Biscay is a convenient place to test temporal changes in genetic structure over cohorts because nurseries are well known in this area (e.g. Le Pape et al. 2003). Nurseries constitute isolated groups all along the year (Dorel et al. 1991; Koutsikopoulos et al. 1995).

\section{Genetic analyses}

Samples used in genetic analysis consisted of small pieces of muscle preserved either dried, frozen, or in ethanol. Samples (Table 1) were analysed for genetic variation at three nuclear-DNA intronic loci using a EPIC-PCR. The set of loci included the first intron of the metallothionein gene, and the third intron of two $\alpha$-amylase genes. The two amylase (Am2B3) loci were amplified with primers defined in Hassan et al. (2002). Further cloning of alleles indicated that alignment of sequences of each amylase locus were not possible (JL Rolland and B Guinand, unpubl. results), indicating that we probably amplified two different genes of the multigenic $\alpha$-amylase gene family (Bouneau et al. 2003). A new set of primers was defined for the metallothionein (MT) locus. The primers MetF (sense: 5'ATGA(CT)CCTTG(CT)GA(AC)TGCTC3') and MetR (antisense: 5'GCAGGA(GT)CCTCCGCAGTTGC3') were designed from the alignment of the metallothionein A gene of the rainbow trout (Onchorhynchus mykiss, GenBank M22487) with homologous cDNA sequences of sea bass (Dicentrarchus 
labrax; GenBank AF199014). Individual PCR amplifications at each locus were carried out in a $10 \mu$ l reaction mixture containing $1 \mu$ l DNA template (50ng), $0,8 \mu M$ of each primer (one primer from each set was 5'- labeled with fluorochrome CY5 (Eurogenetec, Strasbourg, France), $1.5 \mathrm{mM} \mathrm{MgCl} 2$ (Promega, Madison WI, USA), $0.25 \mathrm{mM}$ each dNTP, and 0.05 U Taq polymerase (Promega, Madison WI, USA). Amplification conditions were 35 cycles of denaturation at $94^{\circ} \mathrm{C}$ for $1 \mathrm{~min}$, annealing at $50{ }^{\circ} \mathrm{C}(M T)$ or $48^{\circ} \mathrm{C}$ (Am2B3-1, Am2B3-2) for $1 \mathrm{~min}$ and extension at $72^{\circ} \mathrm{C}$ for $10 \mathrm{~min}$. Amplification products were mixed directly with an equal volume of formamide loading dye (95\% formamide, $20 \mathrm{mM}$ EDTA, $0.05 \%$ xylene cyanol and $0.05 \%$ bromophenol blue) and denatured at $94^{\circ} \mathrm{C}$ for $5 \mathrm{~min}$. Two microliters of the mixture were loaded onto a $6 \%$ denaturing polyacrylamide gel and run using $0.5 \mathrm{X}$ TBE buffer at $50 \mathrm{~W}$ for 3 hrs $(M T), 5$ Hrs (Am2B3-1) and (Am2B3-2). Gels were subsequently laser-scanned at $675 \mathrm{~nm}$ and CY5 fluorescent bands were visualised in an FMBio II fluorescence imaging apparatus (Hitachi Instruments, San José CA, USA).

\section{Data analyses}

Deviations from Hardy-Weinberg expectations within samples were investigated using Weir \& Cockerham's (1984) $f$ using Genetix v.4.05 (Belkhir et al. 1996-2001; available at http://www.univ-montp2.fr/ genetix/). Test of the null hypothesis of no significant departure from Hardy-Weinberg expectations $(f=0)$ was carried by randomly permutating alleles from the original matrix of genotypes using the appropriate procedure in Genetix v.4.05. Levels of pairwise population differentiation were investigated using Weir \& Cockerham's (1984) $\theta$, an estimator of Wright's (1951) $F_{\text {st }}$, also using Genetix v.4.05. In all cases, critical significance levels for multiple testing were also corrected using sequential Bonferroni procedures. Reynold's et al. (1983) distance was used to construct the population phenogram using the neighbour-joining algorithm (Saitou and Nei 1987) implemented in Phylip v3.6.1 (Felsenstein 1993). Population phenogram was computed based on data at the three scored loci, but also for each locus separately. In the multilocus case, confidence in tree topology was assessed by bootstrapping data (1000 iterations). The unrooted trees was displayed using Treeview (Page 1996). Patterns of linkage disequilibrium were computed as Weir (1979), and significance testing carried out by permutations (1000) using Genetix v.4.05. Results were proved not being affected by the choice of distance (i.e., the shape and main relationships among samples in phenograms were found identical). The Reynold's et al. (1983) distance was retained since it is based on Weir \& Cockerham's (1984) $\theta$, offering a coherent metric to interpret phenograms with respect to estimation of (pairwise) genetic differentiation using $\theta$.

Patterns of isolation by distance (IBD) looking at the relationship between pairwise population genetic differentiation (measured by $\theta /(1-\theta)$; Rousset 1997) and geographical distance (log-transformed; measured as the shortest distance by sea) were computed using both the Mantel test and the Pearson correlation coefficient implemented in Genetix v.4.05. Tests (1000 iterations). Such test were computed over the whole range of samples (Atlantic and Mediterranean), then only for Atlantic samples, and both for the multilocus case and for each locus taken separately. For consistency, test were also computed only among subadult samples to avoid some 'noise' due to Bay of Biscay's replicated samples. Mediterranean samples were not considered alone due to low number of samples (Table 1).

\section{Results}

Allelic diversity, gene diversity and Hardy-Weinberg equilibrium

The Am2B3-1, Am2B3-2 and MT loci were characterized by four, three and fourteen different alleles, respectively, with size varying from 354 to 381 base pairs (bp) for locus Am2B3-1, from 240 to 261bp for locus Am2B3-2, and from 106 to 112bp for locus MT. Mean observed heterozygosities across samples were 0.32, 0.53, and 0.63 for locus Am2B3-1, Am2B3-2, and $M T$, respectively. Alleles observed at locus $M T$ were characterized by single-repeat nucleotidic changes (length variation of alleles due to poly-T variation; result not shown), making this locus a microsatellite-like locus. Allelic variation at each amylase loci was characterized by indels (not shown).

Allele frequencies at each locus and in each sample are reported in Table 2, together with expected $\left(H_{\exp }\right)$ and observed $\left(H_{\mathrm{obs}}\right)$ gene diversities, and $f$ values. Only three samples over seventy two cases demonstrated significant departures of Hardy-Weinberg equilibrium at individual locus after Bonferroni correction for multiple testing. Only the MT locus was affected for samples both in the Atlantic (Loire 1+, PA 0+) and the Mediterranean Sea (Aegean) (Table 2). Multilocus estimate of $f$ was significantly distinct from zero in only one population after Bonferroni correction testing (Loire Ad; Table 2). No case of significant linkage disequilibrium was reported for any couple of loci when sequential Bonferroni correction was applied (results not shown). 


\section{Population structure across the whole sample}

Estimates of multilocus $\theta$ indicated significant population differentiation between Atlantic and Mediterranean populations of sole, but also significant differentiation among Mediterranean populations (Table 3). The associated tree based on all analysed loci clearly illustrated genetic distinctiveness of Mediterranean and Atlantic populations (Fig. 2A). From pairwise multilocus estimates of population differentiation (not reported), the population from the Adriatic appeared as the most genetically distinct from all other samples, including the Aegean sample. Conversely, no significant multilocus differentiation between populations was detected among Atlantic populations (Table 3).

Interpretation of results should be slightly qualified when considering each locus separately. It was shown that locus Am2B3-1 displayed patterns found in the multilocus tree, with the Adriatic and Aegean populations being more distantly related to all other populations (Fig. 2B). For locus Am2B3-1, estimates of $\theta$ basically illustrated significant genetic differentiation between Eastern Mediterranean populations, and a group composed by Atlantic and Western Mediterranean populations of sole, whereas no differentiation among Atlantic and Western Mediterranean populations were observed (Table 3). As $\theta$ could level up 0.35, this locus had the strongest impact on the structure of the multilocus tree. As in the multilocus case, locus Am2B3-2 reflected a clear genetic distinction between populations from the Atlantic and the Mediterranean Sea (Fig. 2C and Table 3). No significant differentiations were recorded among Atlantic or Mediterranean samples at this locus (Table 3). However, pairwise values of $\theta$ hence demonstrated significant Bonferroni-corrected genetic differentiation among some Atlantic populations from the Bay of Biscay, mainly involving the PA Ad sample (not reported; but see 'Genetic differentiation among samples' for support of differentiation involving the Pertuis d'Antioche samples). Finally, estimates of $\theta$ at locus MT demonstrated no clear-cut distinction of the Mediterranean or of a set of Mediterranean populations with Atlantic populations (Table 3; see also Fig. 2D). Small but significant Bonferroni corrected genetic differentiation were found between samples from La Coubre and the subadults from the Loire River among of Bay of Biscay populations $(\theta=0.078$; $P<0.05)$, but also between the Western Mediterranean Hérault and Rhône samples $(\theta=0.066 ; P<0.05)$ (not reported).

No significant patterns of IBD were detected for the full set of populations or only Atlantic populations, both in the multi- or single-locus cases. Results were unchanged when considering all populations or only adult populations (details not given).

\section{Genetic differentiation among replicated samples}

No genetic differentiation was found among temporarily replicated sample (except once: locus Am2B3-2 at Pertuis d'Antioche; Table 4), indicating stability in genetic structure at the local scale of Bay of Biscay's estuaries or bays. Nevertheless, results demonstrated that relative differentiation among samples expressed by the ratio of $\theta$ among replicated samples on $\theta$ at the scale of Bay of Biscay was often high (i.e. $>100 \%$ ), indicating more differentiation at a single site than over the Bay of Biscay. A role for chaotic genetic patchiness can then not completely discarded.

\section{Discussion}

This study provides a thorough genetic analysis on populations of the common sole, Solea solea, along the east European Atlantic continental shelf and across the Mediterranean Sea using three EPIC markers. It allows investigating patterns of genetic differentiation through time in the Bay of Biscay populations where several cohorts were sampled at the same location (Fig. 1; Table 1). Using three EPIC markers, the present study re-examined the genetic structure of sole populations along the European Atlantic continental shelf and across the Mediterranean Sea. For most populations of the Bay of Biscay, several cohorts were sampled at the same time, allowing a temporal analysis of the patterns of genetic differentiation. Heterozygosity values that we found (0.32, 0.53, and 0.63 for locus Am2B3-1, Am2B3-2, and $M T$, respectively) are much higher than those observed for allozyme loci (range: 0.03 to 0.11; Exadactylos et al. 1998). Polymorphism observed at the $M T$ locus is based on single-repeat, microsatellite-like variation of alleles (not shown), and exhibited a level of diversity comparable to those obtained for microsatellite loci in sole (range: 0.55-0.83; Garoia et al. 2006).

\section{Genetic differentiation using EPICs : multilocus vs single-locus interpretations}

At the multilocus level, results using EPICs agreed with the differentiation reported among Atlantic and Mediterranean populations using allozymes (Kotoulas et al. 1995; Exadactylos et al. 1998). They also supported eastward-westward differentiation among Mediterranean populations of sole for allozymes (Kotoulas et al. 1995), and mtDNA (Guarniero et al. 2002). This Mediterranean division has been reported in other flatfish (flounder, Platichthys flesus, Borsa et al. 1997b; turbot, Scophthlamus maximus: Suzuki et al. 2004), or roundfish (e.g. sea bass, Dicentrarchus labrax: Bahri-Sfar et al. 2000; mackerel, Scomber scombrus: Zardoya et al. 
2004). However, such a pattern of genetic differentiation within the Mediterranean Sea is not observed in every flatfish species (brill, Scophthalmus rhombus: Blanquer et al. 1992). Finally, the Adriatic population is differentiated from all other Mediterranean populations (Fig. 2A; Table 3). This pattern was already demonstrated in other species (e.g. Sardina pilchardus,Tinti et al. 2002; Mullus barbatus, Garoia et al. 2004; Pomatoschistus minutus, Steffani and Thorley 2003, Gysels et al. 2004), including a flatfish (flounder; Borsa et al. 1997b), but not in sole. Hence, observed multilocus differentiation among sole populations within the Mediterranean using EPICs is in accordance with previous studies that suggested different stocks. Differentiation among such populations could be due to the complex history of the Mediterranean that was strongly impacted during glacial episodes. This may lead to postulate the existence of distinct refuges in the Mediterranean as well as possible partial recolonisation by populations from the Atlantic that would explain westward-eastward differentiation (see details in, e.g. Zardoya et al. 2004; Magoulas et al. 2006). Maintenance of differentiation through time may also be favored by a much higher fragmentation than in the Atlantic due to other factors such as lower densities and lesser suitability of habitats for sole that may prevent gene flow (Sartor et al. 2002).

Conversely to significant multilocus patterns of population differentiation in the Mediterranean, observed genetic variation support large genetic homogeneity for sole populations in the Atlantic, from Portugal to Denmark (Table 3; Fig. 2A). This further extends results from Kotoulas et al. (1995) that indicated genetic homogeneity for Bay of Biscay and English Channel samples, but not for Atlantic samples further south or north that were not previously considered. Hence, as for other flatfishes such as plaice (Hoarau et al. 2002, 2004), flounder (Borsa et al. 1997b), turbot (Nielsen et al. 2004), and sand sole (Solea lascaris, Pinheiro et al. 2005), the Atlantic population of sole could function as one single panmictic unit. Exadactylos et al. (2003) indicated however differentiation of sole populations around the British Isles.

If interpretation of the multilocus patterns of spatial genetic differentiation in sole using EPICs was consistent with previously published studies using allozymes and mtDNA in sole, and with results pertaining to many other fish species, separate results from each single EPIC marker highlighted a very particular pattern of differentiation (Fig. 2B, C, D). Namely, locus Am2B3-2 revealed a clear-cut Mediterranean-Atlantic differentiation, but no significant differentiation within the Mediterranean or Atlantic populations was observed (Table 3; Fig. 2C). Such a pattern was reported for the bonito (Sarda sarda, Pujolar et al. 2001; Viñas et al. 2004), and the brill (Blanquer et al. 1992). On the other hand, locus Am2B3-1 demonstrated differentiation within the Mediterranean basin, separating the Eastern Mediterranean populations from all the other populations (Fig. 2B). This pattern was also reported in the mackerel, the bluefin tuna (Thunnus thynnus thynnus) and various sparids (Bargelloni et al. 2003; Carlsson et al. 2004; Zardoya et al. 2004), and was interpreted as a results of secondary contact after allopatric divergence. At locus $M T$, genetic differentiation between the Mediterranean and Atlantic was not supported. Absence of genetic differentiation among Atlantic and Mediterranean populations was also recorded in chub mackerel (Scomber japonicus, Zardoya et al. 2004), white anglerfish (Lophius piscatorius, Charrier et al. 2006), and blue jack and horse mackerels (Trachurus picturatus and T. trachurus, respectively, Karaiskou et al. 2004). In sole, the absence of differentiation could be due to effect of the microsatellite-like genetic diversity scored at locus $M T\left(H_{\mathrm{obs}}=0.63\right)$. Theory demonstrated that microsatellite-like markers with high gene diversity exhibited lower and often not significant levels of population differentiation (see O'Reilly et al. 2004 for details). Using fourteen microsatellite loci, O’Reilly et al. (2004) demonstrated such a relationship in walleye pollock (Theragra chalcogramma). Nevertheless, this hypothesis is rather unlikely at locus $M T$ in sole as this phenomenon was primarily recorded for locus with $H_{\text {obs }}>0.7$ (Olsen et al 2004; O’Reilly et al 2004).

Whatever the mechanisms underlying genetic divergence at particular locus such as locus $M T$, the concordance of pattern of differentiation across multiple loci within a species are essential to the definition of true phylogeographical boundaries (Avise 1998). Such a concordance is then clearly not reach in sole, and the disparate single-locus patterns of genetic differentiation - hence the different genealogies and levels of gene flow - observed in this study indicate that history of sole in the Mediterranean Sea and the Eastern Atlantic is complex and that any multilocus summary as described above should be cautiously considered. Because most recent studies dealing with population structure of marine fishes in the Atlantic and the Mediterranean were mostly based on patterns of variation at one mtDNA locus, they very often revealed only one of the aforementioned pattern at the species level. For instance, comparative studies of population structure for five sparids provided by Bargelloni et al. (2003) revealed that each species exhibited one unique pattern of mtDNA differentiation between the Atlantic and the Mediteranean (i.e. presence or absence of significant genetic variation between water bodies; hence mostly the presence of one or two mtDNA clades). Similar results were found by Zardoya et al. (2004) and Charrier et al. (2006). As results based on mtDNA data are aimed to investigate historical demography of species, they might be incomplete and complementary analyses of variation at nuclear genes. EPICs (e.g. Palumbi and Baker 1994; Durand et al. 2005; Hickerson and Cunningham 2005; this study), allozymes (e.g. 
Bargelloni et al. 2003), or microsatellites (e.g. Carlsson et al. 2004) can provide reliable information to interpret evolutionary history of the species more thoroughly (Hare 2001; Buonaccorsi et al. 2001). Studies that jointly used different markers to investigate differentiation within and among the Eastern Atlantic and the Mediterranean Sea division are scarce (De Innocentiis et al. 2001; Bargelloni et al. 2003; Carlsson et al. 2004; Lemaire et al. 2005). To our knowledge, only two studies in this area considered variation at one intronic marker (Ely et al. 2002; Nakadate et al. 2005). Among those studies, only Bargelloni et al. (2003) reported discordance in patterns of genetic differentiation among markers (i.e., allozymes and mtDNA) for two over five sparids species they studied (Pagrus pagrus, Pagellus bogaraveo). Data for sole are the first ones to report such differences in patterns of genetic differentiation within a single class of polymorphic nuclear loci (even though microsatellite-like polymorphism to locus $M T)$.

Such distinct signals of genetic differentiation among EPIC markers may be due to stochastic variation occurring among gene tree topologies because of different, but possibly all confirming to neutral expectations, demographic histories of each gene. Nevertheless, as levels of differentiation could reach quite distinct values across loci, we may hypothesize that drift and gene flow are not the only causes for the observed genetic variation, but that effect of late and recent population history combined with selection in shaping the genetic structure of sole populations. Testing for selection is difficult as most reliable tests for selection imply more loci ( $\geq 10$; review in Beaumont 2005), and/or specific type of loci (e.g. microsatellites; Schlötterer 2002). EPIC markers are considered as being neutral, but they may be indirectly subject to selection by the so-called Hill-Robertson effect (e.g. Barton 2000). In such a case, selection truly acts on neighbouring coding nucleotidic sites, but its effects may also be detectable across a stretch of DNA sequence whose length depends on recombination rate and effective population size. Selective hypothesis in shaping observed of Atlantic-Mediterranean differentiation is long-standing, but is traditionally overcome by purely neutral scenarios implying historical and demographic processes. However, Cimmaruta et al. (2005) recently demonstrated clinal variation matching temperature and salinity variations for hake (Merluccius merluccius) across the Mediterranean was very probably selective and not resulting from secondary contact (see also Launey et al. 2002 in flat oyster, Ostrea edulis).

\section{Temporal differentiation within Bay of Biscay estuaries}

Temporal differentiation among cohorts at single locales has been poorly investigated in sole. Only Kotoulas et al. (1995) addressed this issue and demonstrated moderate differentiation when comparing one adult (sampled in 1981) and three juveniles (successively sampled in 1986) cohorts in the Vilaine estuary. In this study, whatever the location considered, no genetic multilocus differentiation was found among temporally replicated samples of the Bay of Biscay (Tables 3 and 4). Only locus Am2B3-2 indicated significant differentiation among juveniles and adult samples, but due to Pertuis d'Antioche samples only (Table 4). Absence of multilocus temporal genetic differentiation supports the expectation drawn from biological data because of the mixing in spawning areas of mature individuals originating from adjacent nurseries, and because of probably passive diffusion of eggs and larvae to nursery areas (Dorel et al. 1991; Koutsikopoulos et al. 1991). Hoarau et al. (2005) also reported absence of genetic differentiation among cohorts in plaice, both for one North Sea and one Icelandic populations. As sole and plaice share most main life-history features (e.g. high fecundity), observed panmixia at both a local (among samples taken at one location; Table 4) and a more global (Atlantic; Table 4) scale is not really surprising. Nevertheless, we demonstrated that in most cases, genetic variation among temporal samples within estuarine/coastal population clearly exceeded the geographical component (i.e., among Bay of Biscay's subadult samples) (Table 4). This might indicate that despite one overall context that favoured panmixia, other mechanisms promoting subtle genetic patchiness a local scale might act in the genetic structuring of populations (Maes et al. 2006). As noted by Dannewitz et al. (2005), the statistical power in the within-population (temporal) analyses becomes low because of small sample sizes. This might participate to the many non-significant comparisons observed in sole (Table 4). Interestingly, it was shown in flounder that some alleles and/or allelic combinations of few allozymic loci were favored in estuaries of Loire, Vilaine and Gironde, possibly indicating genetic patchiness due to selective effects, whereas alleles at other loci were not (Marchand et al. 2003). Results pertaining to locus Am2B3-2 at Pertuis d'Antioche can be interpreted in this way, and both non-selective and selective hypothesis still need to be thoroughly investigated.

Hence, further works at the spatial (i.e., investigation about patterns of differentiation of the distinct loci) and the temporal (i.e., stability of genetic structure across cohorts at a given location) levels should also help to define more precisely how drift and/or selection combine in sole populations.

Acknowledgements - We are grateful to staffs of IFREMER vessels for sampling most of Bay of Biscay populations, with special thanks to Y. Désaunay for Loire and Vilaine samples, and E. Nielsen (Denmark) that provided the Kattegat sample. The Rhône sample was a kind gift of 
M. Harmelin-Vivien (U. Aix-Marseille 2). Thanks also to F. Volckaert for sharing with us the samples from Venice and Thessaloniki. Many thanks to J.-F. Agnèse, G. Claireaux, J.-D. Durand, F. Lecomte, O. Le Pape and C. Gilliers for fruitful discussions and inputs. We acknowledge IFREMER and the "Défi Golfe de Gascogne” for funding this research.

\section{References}

Anonymous (2003) Report of the working group on the assessment of southern shelf demersal stocks. ICES CM 2003/ACFM 03.

Avise JC (1998) The history and purview of phylogeography: a personal reflection. Mol Ecol 7: 371-379.

Bahri-Sfar L, Lemaire C, Ben Hassine OK, Bonhomme F (2000) Fragmentation of sea bass populations in the western and eastern Mediterranean as revealed by microsatellite polymorphism. Proc R Soc B267: 929 -935.

Bargelloni L, Alarcon JA, Alvarez MC, Penzo E, Magoulas A, Reis C, Patarnello T (2003) Discord in the family Sparidae (Teleostei): divergent phylogeographical patterns across the Atlantic-Mediterranean divide. J Evol Biol 16: 1149-1158.

Bargelloni L, Alarcon JA, Alvarez MC, Penzo E, Magoulas A, Palma J, Patarnello T (2005) The Atlantic-Mediterranean transition: discordant genetic patterns in two seabream species, Diplodus puntazzo (Cetti) and Diplodus sargus (L.). Mol Phylogenet Evol 36: 523-535.

Barton NH (2000) Genetic hitchhiking. Phil Trans R Soc Lond B355: 1553-1562.

Beardmore JA,Ward RD (1977) Polymorphism, selection, and multilocus heterozygosity in the plaice, Pleuronectes platessa L. Lect Notes Biomath 19: 207 -221.

Beaumont M (2005) Adaptation and speciation: what can $F_{\text {st }}$ tell us? Trends Ecol Evol 20: 435440.

Belkhir K, Borsa P, Chikhi L, Raufaste N, Bonhomme F (1996-2001) Genetix v .4 .03, Logiciel sous Windows ${ }^{\mathrm{TM}}$ pour la Génétique des Populations. Laboratoire Génome et Population, Université Montpellier 2, Montpellier.

Blanquer A, Alayse JP, Berrada-Rkhami O, Berrebi P (1992) Allozyme variation in turbot (Psetta maxima) and brill (Scophthalmus rhombus) (Osteichthyes, Pleuronectiformes, Scophthalmidae) throughout their range in Europe. J Fish Biol 41: 725 -736.

Bouneau L, Lardier G, Fischer C, Ronsin M, Weissenbach J, Bernot A (2003) Analysis of $148 \mathrm{~kb}$ of genomic DNA of Tetraodon nigroviridis covering an amylase gene family. DNA Seq 14: 1-13.

Borsa P, Naciri M, Bahri L, Chikhi L, Garcia de Leon FJ, Kotoulas G, Bonhomme F (1997a) Zoogéographie infra-spécifique de la mer Méditerranée : analyse des données génétiques populationnelles sur seize espèces atlanto-méditerranéennes (Poissons et Invertébrés). Vie Milieu 47: 295 -305.

Borsa P, Blanquer A, Berrebi P (1997b) Genetic structure of the flounders Platichthys flesus and P.stellatus at different geographic scales. Mar Biol 129 : $233-246$.

Buonaccorsi VP, McDowell JR, Graves JE (2001) Reconciling patterns of inter-ocean molecular variance from four classes of molecular markers in blue marlin (Makaira nigricans). Mol Ecol 10: 1179-1196.

Cabral HN, Castro F, Linhares D, Alexandrino P (2003) Genetic differentiation of Solea solea (Linnaeus, 1758) and S. senegalensis Kaup, 1858, (Pisces: Pleuronectiformes) from several estuarine systems of the Portuguese coast. Sci Mar 67: 43-52.

Carlsson J, McDowell JR, Díaz-Jaimes P, Carlsson JEL, BolesSV, Gold JR, Graves JE (2004) Microsatellite and mitochondrial DNA analyses of Atlantic bluefin tuna (Thunnus thynnus thynnus) population structure in the Mediterranean Sea. Mol Ecol 13: 3345-3356.

Castillo AGF, Alvarez P, Garcia-Vazquez E (2005) Population structure of Merluccius merluccius along the Iberian Peninsula coast. ICES J Mar Sci 62 : 1699-1704.

Chapman, Ball AO, Mash LR (2002) Spatial homogeneity and temporal heterogeneity of red drum (Sciaenops ocellatus) microsatellites: effective population sizes and management implications. Mar Biotechnol 4: 589-603.

Charrier G, Chenel T, Durand JD, Girard M, Quiniou L, Laroche J (2006) Discrepancies in phylogeographical patterns of two European anglerfishes (Lophius budegassa and Lophius piscatorius). Mol Phyl Evol 38: 742-754.

Cimmaruta, R., Bondanelli P., Nascetti, G. (2005) Genetic structure and environmental heterogeneity in the European hake (Merluccius merluccius). Mol Ecol 14: 2577-2591.

De Innocentiis S, Sola L, Cataudella S, Bentzen P (2001) Allozyme and microsatellite provide discordant estimates of population differentiation in the endangered dusky grouper (Epinephelus marginatus) within the Mediterranean Sea. Mol Ecol 10: 2163-2175.

Dorel D, Koutsikopoulos C, Désaunay Y, Marchand J (1991) Seasonal distribution of young sole (Solea solea (L.) in the nursery ground of the Bay of Vilaine (Northern Bay of Biscay). Neth J Sea Res 27: 297-306.

Durand JD, Collet A, Chow S, Guinand B, Borsa P (2005) Nuclear and mitochondrial DNA markers indicate unidirectional gene flow of Indo-Pacific to Atlantic bigeye tuna 
(Thunnus obesus) populations, and their admixture off southern Africa. Mar Biol 147: 313-322.

Ely B, Stoner DS, Alavarado-Bremer JR, Dean JM, Addis P, Cau A, Thelen EJ, Jones WJ, Black DE, Smith L, Scott K, Naseri I, Quattro JM (2002) Analyses of IdhA gene and mitochondrial control region of Atlantic northern bluefin tuna populations. Mar Biotechnol 4: 583-588.

Exadactylos A, Geffen AJ, Thorpe JP (1998) Population structure of the Dover sole, Solea solea L., in a background of high gene flow. Neth J Sea Res 40: $117-129$.

Exadactylos A, Geffen AJ, Panagiotaki P, Thorpe JP. (2003) Population structure of Dover sole Solea solea: RAPD and allozyme data indicate divergence in European stocks. Mar Ecol Prog Ser 246: 253-264.

Felsenstein J (1993) Phylip: phylogeny inference package, v. 3.5c. Seattle, WA: Department of Genetics, University of Washington.

Garoia F, Guarniero I, Piccinetti C, Tinti F. (2004) First microsatellite loci of red mullet (Mullus barbatus) and their applications to genetic structure analysis of Adriatic shared stock. Mar Biotechnol 6: 446-452.

Garoia F, Marzola S, Guarniero I, Trentini M, Tinti F (2006) Isolation of polymorphic DNA microsatellites in the common sole, Solea vulgaris. Mol Ecol Notes 6 : 144-146.

Guarniero I, Franzellitti S, Ungaro N, Tommasini S, Piccinetti C, Tinti F (2002) Control region haplotype variation in the central Mediterranean common sole indicates geographical isolation and population structuring in Italian stocks. J Fish Biol 60: 1459-1474.

Gysels ES, Hellemans B, Patarnello T, Volckaert FAM (2004) Current and historic gene flow of the sand goby Pomatoschistus minutes on the European Continental Shelf and in the Mediterranean Sea. Biol J Linn Soc 83: 561-576.

Hare MP (2001) Nuclear genes phylogeography. Trends Ecol Evol 16: 700-706.

Hassan M, Lemaire C, Fauvelot C, Bonhomme F (2002) Seventeen new exon-primed intron-crossing polymerase chain reaction amplifiable introns in fish. Mol Ecol Notes 2: 334-340.

Hedgecock D (1994) Temporal and spatial genetic-structure of marine animal populations in the California current. California Coop Ocean Fish Inv Rep 35: 73-81.

Hickerson MJ, Cunningham CW (2005) Contrasting quaternary histories in an ecologically divergent sister pair of low-dispersing intertidal fish (Xiphister) revealed by multilocus DNA analysis. Evolution 59: 344-360.

Hoarau G, Rijnsdorp AD, van der Veer HW, Stam WT, Olsen JL (2002) Population structure of plaice (Pleuronectes platessa L.) in northern Europe: microsatellites revealed large scale spatial and temporal homogeneity. Mol Ecol 11: 1165-1176.

Hoarau G, Piquet AMT, van der Veer HW, Rijnsdorp AD, Stam WT, Olsen JL (2004) Population structure of plaice (Pleuronectes platessa L.) in northern Europe: a comparison of resolving power between microsatellites and mitochondrial DNA data. J Sea Res 51: 183-190.

Hutchinson WF, Carvalho GR, Rogers SI (2001) Marked genetic structuring in localised spawning populations of cod Gadus morhua in the North Sea and adjoining waters, as revealed by microsatellites. Mar Ecol Prog Ser 223: 251-260.

Johnson MS, Black R (1982) Chaotic patchiness in an intertidal limpet, Siphonaria sp. Mar Biol 70: 157-164.

Karaiskou N, Triantafyllidis A, Triantaphyllidis C (2004) Shallow genetic structure of three species of the genus Trachurus in European waters. Mar Ecol Prog Ser 281: 193-205.

Kenchington E, Heino M, Nielsen EE (2003) Managing marine genetic diversity: time for action? ICES J Mar Sci 60 : 1172-1176.

Knutsen H, André C, Jorde PE, Skogen MD, Thuròczy E, Stenseth NC (2004) Transport of North Sea cod larvae into the Skagerrak coastal populations. Proc R Soc B271: 13371344.

Kotoulas G, Bonhomme F, Borsa P (1995) Genetic structure of the common sole Solea vulgaris at different geographic scales. Mar Biol 122: 361 - 375.

Koutsikopoulos C, Fortier L, Gagné J (1991) Cross-shelf dispersion of Dover sole eggs and larvae (Solea solea) in Biscay Bay and recruitment to inshore nurseries. J Plankton Res 13: 923-945.

Koutsikopoulos C, Dorel D, Désaunay Y (1995) Movement of sole Solea solea (L.) in the Bay of Biscay: coastal environment and spawning migration. J Mar Biol Assoc UK 75: 109126.

Launey S, Ledu C, Boudry P, Bonhomme F, Naciri-Graven H (2002) Geographic structure in the European flat oyster (Ostrea edulis L.) as revealed by microsatellite polymorphism. J Hered 93: 331-338.

Léauté JP, Caill-Milly N (2003) Les petites pêches côtières et estuariennes françaises de sud du Golfe de Gascogne. Final Report PECOSUD EC/DG Fish (DG XIV) No. 99/024, IFREMER, DRV/RH/DT/03-01. 
Lemaire C, Versini JJ, Bonhomme F (2005) Maintenance of genetic differentiation across a transition zone in the sea: discordance between nuclear and cytoplasmic markers. J Evol Biol 18: 70-80.

Le Pape O, Chauvet F, Mahévas S, Lazure P, Guérault D, Désaunay Y (2003) Quantitative description of habitat suitability for the juvenile common sole (Solea solea, L.) in the Bay of Biscay (France) and the contribution of different habitats to the adult population. J Sea Res 50: 139-149.

Maes GE, Pujolar JM, Hellemans B, Volckaert FAM (2006) Evidence for isolation by time in the European eel (Anguilla anguilla L.). Mol Ecol 15: 2095-2107.

Magoulas A, Castilho R, Caetano S, Marcato S, Patarnello T (2006) Mitochondrial DNA reveals a mosaic pattern of phylogeographical structure in Atlantic and Mediterranean populations of anchovy (Engraulis encrasicolus). Mol Phylogenet Evol doi:10.1016/j.ympev.2006.01.016

Marchand J, Tanguy A, Laroche J, Quiniou L, Moraga D (2003) Responses of European flounder Platichthys flesus populations to contamination in different estuaries along the Atlantic coast of France. Mar Ecol Prog Ser 260: 273- 284.

Mariani S, Hutchinson WF, Hatfield EMC, Ruzzante DE, Simmonds EJ, Dahlgren TG, André C, Brigham J, Torstensen E, Carvalho GR (2005) North Sea herring population structure as revealed by microsatellite analysis. Mar Ecol Prog Ser 303: 245-257.

Naciri M, Lemaire C, Borsa P, Bonhomme F (1999) Genetic study of the Atlantic/Mediterranean transition in sea bass (Dicentrarchus labrax). J Hered 90: 591 596.

Nakadate M, Viñas J, Corriero A, Clarke S, Suzuki M, Chow S (2005) Genetic isolation between Atlantic and Mediterranean albacore populations inferred from mitochondrial and nuclear DNA markers. J Fish Biol 66: 1545-1557.

Nesbø CL, Rueness EK, Iversen SA, Skagen DW, Jakobsen KS (2000) Phylogeography and population history of Atlantic mackerel (Scomber scombrus L.): a genealogical approach reveals genetic structuring among the eastern Atlantic stocks. Proc R Soc Lond B267: 281-292.

Nielsen EE, Hansen MM, Ruzzante DE, Meldrup D, Grønkjær P (2003) Evidence of a hybridzone in Atlantic cod (Gadus morhua) in the Baltic and the Danish Belt Sea, revealed by individual admixture analysis. Mol. Ecol. 12: 1497-1508.

Nielsen EE, Nielsen PH, Meldrup D, Hansen MM (2004) Genetic population structure of turbot (Scophthalmus maximus L.) supports the presence of multiple hybrid zones for marine fishes in the transition zone between the Baltic Sea and the North Sea. Mol Ecol 13: 585595.

Reynolds J, Weir BS, Cockerham CC (1983) Estimation of the co-ancestry coefficient - basis for a short term genetic distance. Genetics 105: 767-779.

Olsen JB, Habicht C, Reynolds J, Seeb JE (2004) Moderate and highly polymorphic microsatellites provide discordant estimates of population divergence in sockeye salmon (Oncorhynchus nerka). Env Biol Fish 69: 261-273.

O’Reilly PT, Canino MF, Bailey KM, Bentzen P (2004) Inverse relationship between $F_{\text {ST }}$ and microsatellite polymorphism in the marine fish, walleye pollock (Theragra chalcogramma): implications for resolving weak population structure. Mol Ecol 13: $1799-1814$

Palumbi SR, Baker CS (1994) Contrasting population structure from nuclear intron sequences and mtDNA in humpback whales. Mol Biol Evol 11: 426-435.

Page RDM (1996) TreeView: an application to display phylogenetic trees on personal computers. Comp Appl Biol Sci 12: 357-358.

Planes S, Lenfant P (2002) Temporal change in the genetic structure between and within cohorts of a marine fish, Diplodus sargus, induced by a large variance in individual reproductive success. Mol Ecol 11: 1515-1524.

Planes S, Romans P (2004) Evidence of genetic selection for growth in new recruits of a marine fish. Mol Ecol 13: 2049-2060.

Pinheiro A, Teixeira CM, Rego AM, Marques JF, Cabral HM (2005) Genetic and morphological variation of Solea lascaris (Risso, 1810) along the Portuguese coast. Fish Res 73: 67-78.

Pujolar JM, Roldán MI, Pla C (2001) Allozyme differentiation of bonito in the Mediterranean sea. J Fish Biol 59: 169-174.

Quéro JC, Desoutter M, Lagardère F (1986) Soleidae. In: Whitehead PJP, Bauchot ML, Hureau JC, Tortonese E (Eds), Fishes of the north-eastern Atlantic and Mediterranean. Vol. 3. Paris, Unesco, p. 1308-1324.

Ruzzante DE, Taggart CT, Cook D (1996) Spatial and temporal variation in the genetic composition of a larval cod (Gadus morhua) aggregation; Cohort contribution and genetic stability. Can J Fish Aquat Sci 53: 2695-2705.

Ruzzante DE, Mariani S, Bekkevold D, and 14 co-authors (2006) Biocomplexity in a highly migratory pelagic fish, Atlantic herring. Proc R Soc B 273 : 1459-1464. 
Saitou N, Nei M (1987) The neighbour-joining method: a new method for reconstructing phylogenetic trees. Mol Biol Evol 4: 406-425.

Sartor P, Sbrana M, Ungaro N, Marano CA, Piccinetti C, Manfrin GP (2002) Distribution and abundance of Citharus linguatula, Lepidorhombus boscii, and Solea vulgaris (Osteichthyes : Pleuronectiformes) in the Mediterranean sea. Sci Mar 66 (Suppl. 2): 83102.

Schlötterer C (2002) A microsatellite-based multilocus screen for the identification of local selective sweeps. Genetics 160, 753- 763.

Steffanni S, Thorley JH (2003) Mitochondrial DNA phylogeography reveals the existence of an Evolutionarily Significant Unit of the sand goby Pomatoschistus minutus in the Adriatic (Eastern Mediterranean). Mol Phylogenet Evol 28: 601-609.

Suzuki N, Nishida M, Yoseda K, ÜstÜndağ C, Şahin T, Amaoka K (2004) Phylogeographic relationships within the Mediterranean turbot inferred by mitochondrial DNA haplotype variation. J Fish Biol 65: 580-585.

Tinti F, Di Nunno C, Guarniero I, Talenti M, Tommasini S, Fabbri E, Piccinetti C (2002) Mitochondrial DNA sequence variation suggests the lack of genetic heterogeneity in the Adriatic and Ionian stocks of Sardina pilchardus. Mar Biotech 4: 163-172.

Viñas J., Alvarado Bremer J, Pla C (2004) Phylogeography of the Atlantic bonito (Sarda sarda) in the northern Mediterranean: the combined effects of historical vicariance, population expansion, secondary invasion, and isolation by distance. Mol Phylogenet Evol 33: 32-42.

Weir BS (1979) Inference about linkage disequilibrium. Biometrics 31: 235-254.

Weir BS, Cockerham CC (1984) Estimating F-statistics for the analysis of population structure. Evolution 38: 1358 -1370.

Wright S (1951) The genetical structure of populations. Ann Eugen 15: 323-354.

Zardoya R, Castilho R, Grande C, Favre-Krey L., Caetano S., Marcato S., Krey G., Patarnello T (2004) Differential population structuring of two closely related fish species, the mackerel (Scomber scombrus) and the chub mackerel (Scomber japonicus), in the Mediterranean Sea. Mol Ecol 13: 1785-1798. 


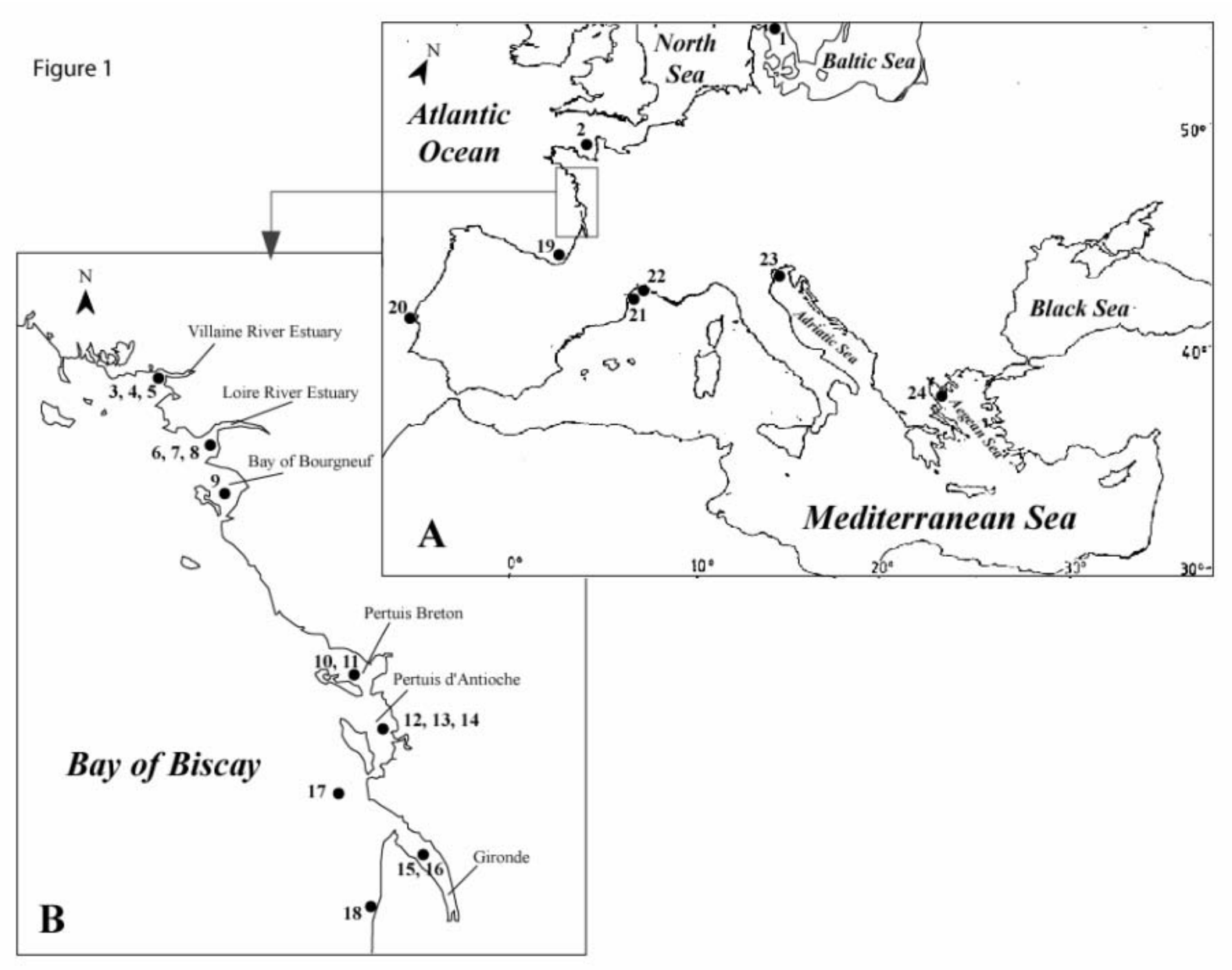

Figure 1: Sampling locations for common sole, Solea solea, in Northeastern Atlantic and Mediterranean Sea. A - Overall distribution of sampling locations; B - Bay of Biscay samples. Several numbers located close a single dot indicate sampling of distinct samples at the same place . Details are provided in Table 1.

Figure 2
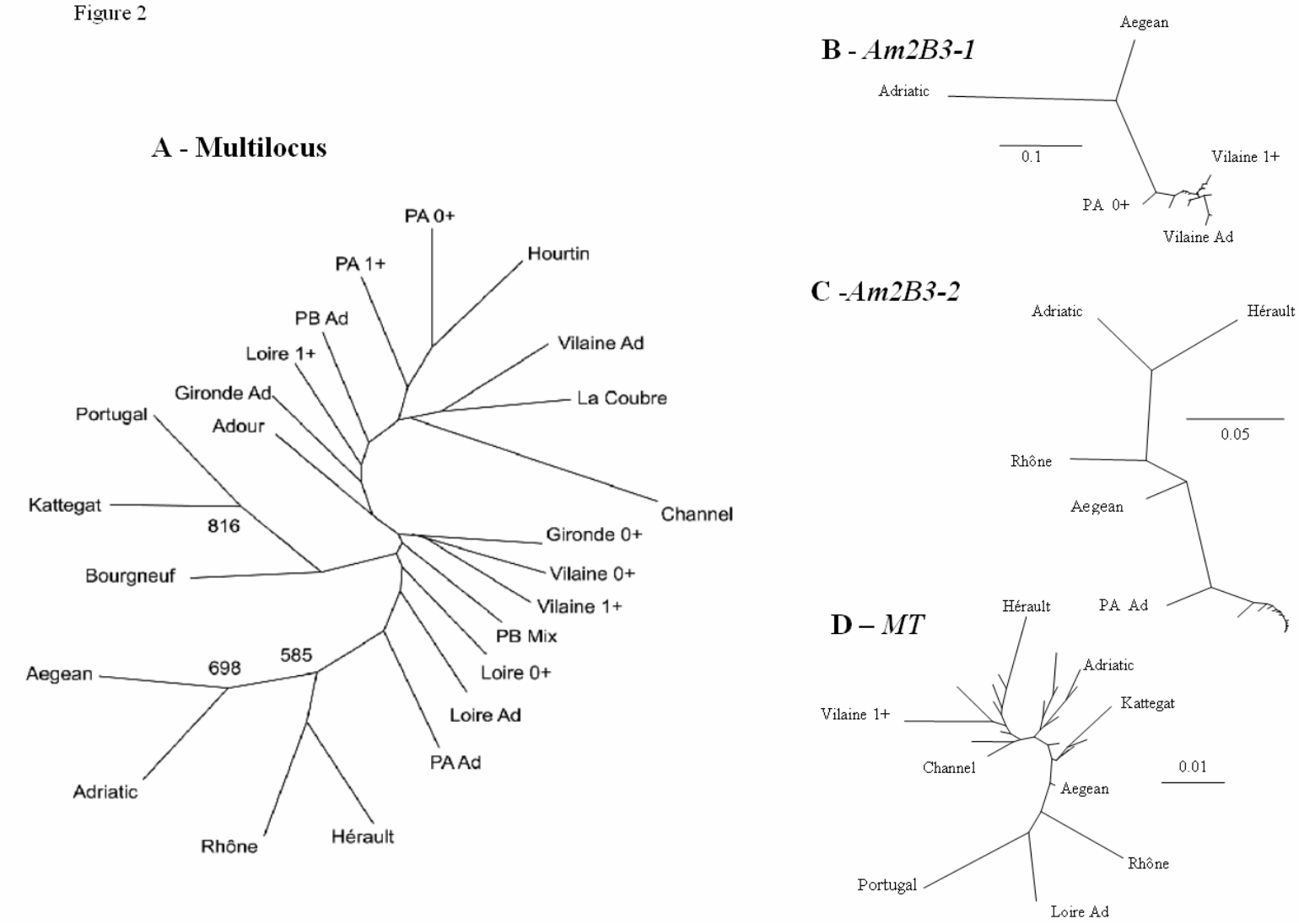

Figure 2: A - Multilocus neighbour-joining tree of the 24 sole samples based on distance proposed by Reynolds et al.'s (1983). The set of Mediterranean populations is highlighted. Names of samples as in Table 1. Bootstrap values of more than 0.50 are given. Neighbour-joining tree of sole samples for: B - locus Am2B3-1. C - locus Am2B3-2, and D - locus MT. In single locus analyses, names of most samples were not indicated because of space requirement. 
Table 1: Sole samples considered in this study. Dates of sampling and age of individuals in each sample are given. $n$ represents the individual sample size.

\begin{tabular}{|c|c|c|c|c|c|c|}
\hline Sample & Label & Specific location & & $\begin{array}{l}\text { Sampling } \\
\text { date }\end{array}$ & $n$ & Age \\
\hline $\begin{array}{l}\text { North Sea-Baltic } \\
\text { Sea }\end{array}$ & 1 & Kattegat & Denmark, North Sea-Baltic Sea transition & 2003 & 30 & Subadults \\
\hline \multirow[t]{19}{*}{ Atlantic } & 2 & English Channel & St Brieuc Bay & 2003 & 30 & Subadults \\
\hline & 3 & Vilaine & Bay of Biscay, Vilaine estuary & 2000 & 30 & Subadults \\
\hline & 4 & Vilaine & Bay of Biscay, Vilaine estuary & 2001 & 30 & $0+$ \\
\hline & 5 & Vilaine & Bay of Biscay, Vilaine estuary & 2001 & 30 & $1+$ \\
\hline & 6 & Loire & Bay of Biscay, Loire estuary & 2000 & 30 & Subadults \\
\hline & 7 & Loire & Bay of Biscay, Loire estuary & 2001 & 30 & $0+$ \\
\hline & 8 & Loire & Bay of Biscay, Loire estuary & 2001 & 30 & $1+$ \\
\hline & 9 & Bourgneuf & Bay of Biscay, Bay of Bourgneuf & 2000 & 30 & Subadults \\
\hline & 10 & Pertuis Breton Mix & Bay of Biscay & 2001 & 70 & Mix $0+, 1+$ \\
\hline & 11 & Pertuis Breton & Bay of Biscay & 2000 & 30 & Subadults \\
\hline & 12 & Pertuis d'Antioche & Bay of Biscay & 2000 & 30 & Subadults \\
\hline & 13 & Pertuis d'Antioche & Bay of Biscay & 2001 & 30 & $0+$ \\
\hline & 14 & Pertuis d'Antioche & Bay of Biscay & 2001 & 30 & $1+$ \\
\hline & 15 & Gironde & Bay of Biscay, Garonne River estuary & 2000 & 29 & Subadults \\
\hline & 16 & Gironde & Bay of Biscay, Garonne River estuary & 2000 & 30 & $0+$ \\
\hline & 17 & Gironde & Bay of Biscay, off Gironde estuary (La Coubre) & 2001 & 30 & Subadults \\
\hline & 18 & Gironde & Bay of Biscay, south Gironde estuary (Hourtin) & 2001 & 30 & Subadults \\
\hline & 19 & Adour & Bay of Biscay, Adour River estuary & 2001 & 30 & Subadults \\
\hline & 20 & Portugal & Algarve, off Faro & 2002 & 23 & Subadults \\
\hline Mediterranean & 21 & Hérault & Gulf of Lions, off Hérault River estuary & 2001 & 30 & Subadults \\
\hline \multirow[t]{3}{*}{ Sea } & 22 & Rhône & Gulf of Lions, off Rhône River estuary & 2002 & 30 & Subadults \\
\hline & 23 & Adriatic & Adriatic Sea, off Venice & 2002 & 29 & Subadults \\
\hline & 24 & Aegean & Aegean Sea, off Thessaloniki & 2002 & 27 & Subadults \\
\hline
\end{tabular}

Dates of sampling and age of individuals in each sample are given. $n$ represents the individual sample size 


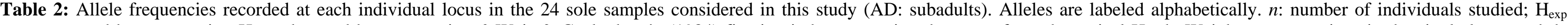

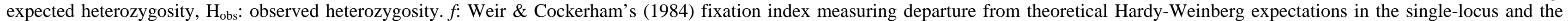
multilocus cases. HWE indicates departures from equilibrium (corrected for multiple test; *: $P<0.05$; ***: $P<0.001$; NS: not significant).

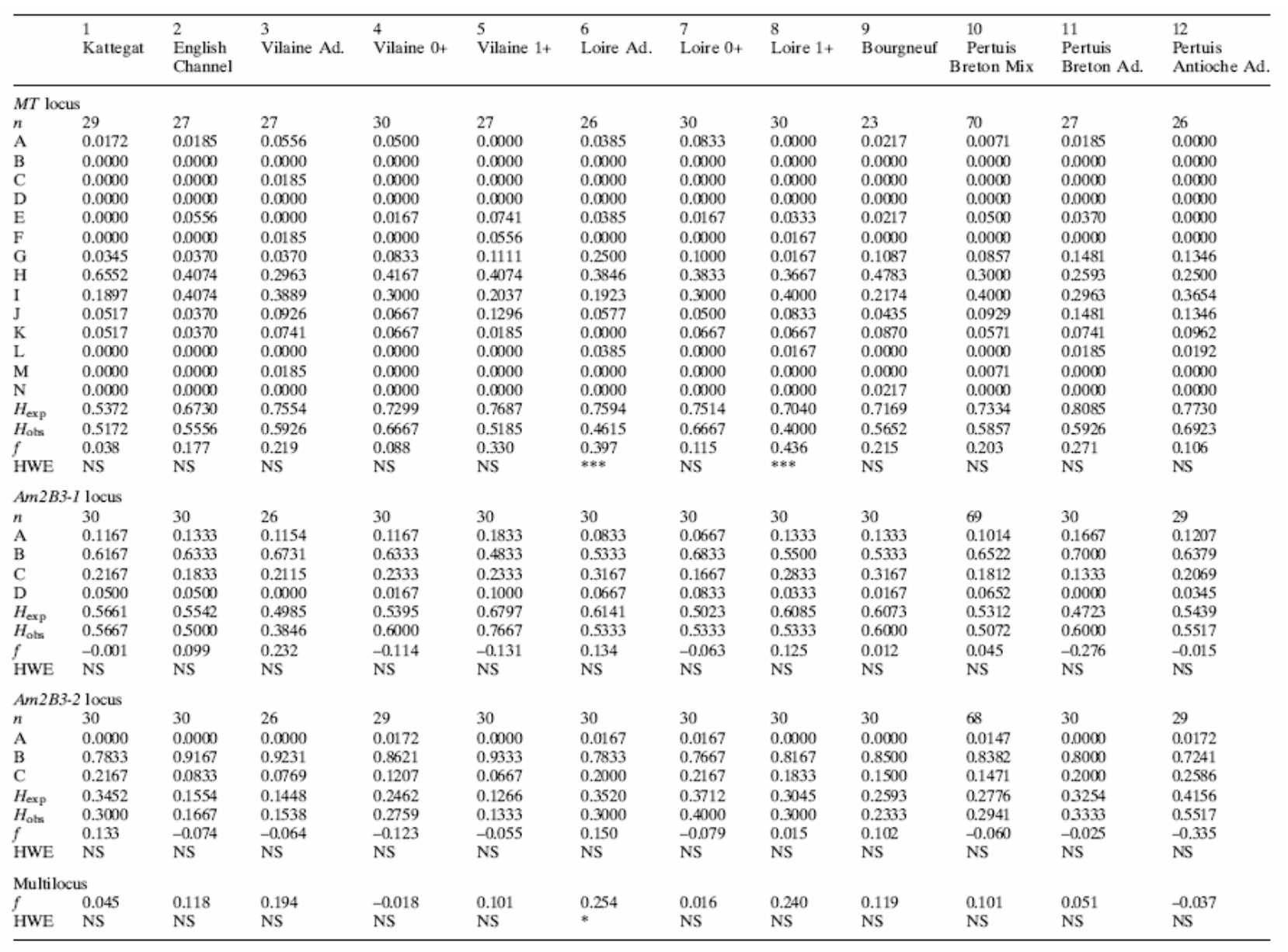




\begin{tabular}{|c|c|c|c|c|c|c|c|c|c|c|c|c|}
\hline & $\begin{array}{l}13 \\
\text { Pertuis } \\
\text { Antioche 0+ }\end{array}$ & $\begin{array}{l}14 \\
\text { Pertuis } \\
\text { Antioche 1+ }\end{array}$ & $\begin{array}{l}15 \\
\text { Gironde } \\
\text { Ad. }\end{array}$ & $\begin{array}{l}16 \\
\text { Gironde } \\
0+\end{array}$ & $\begin{array}{l}17 \\
\text { Gironde Ad. } \\
\text { La Coubre }\end{array}$ & $\begin{array}{l}18 \\
\text { Gironde } \\
\text { Ad. Hourtin }\end{array}$ & $\begin{array}{l}19 \\
\text { Adour }\end{array}$ & $\begin{array}{l}20 \\
\text { Portugal }\end{array}$ & $\begin{array}{l}21 \\
\text { Hérault }\end{array}$ & $\begin{array}{l}22 \\
\text { Rhône }\end{array}$ & $\begin{array}{l}23 \\
\text { Adriatic }\end{array}$ & $\begin{array}{l}24 \\
\text { Aegean } \\
\text { Sea }\end{array}$ \\
\hline \multicolumn{13}{|c|}{ MT locus } \\
\hline$n$ & & & 27 & 29 & & 29 & & 18 & & & & \\
\hline$\underset{B}{A}$ & 0.0000 & 0.0000 & 0.0370 & 0.0000 & 0.0179 & 0.0000 & 0.0167 & 0.0556 & 0.0000 & 0.0769 & 0.0000 & 0.0208 \\
\hline $\begin{array}{l}\mathrm{B} \\
\mathrm{C}\end{array}$ & 0.0000 & 0.0000 & 0.0000 & 0.0000 & 0.0000 & 0.0000 & 0.0000 & 0.0278 & 0.0000 & 0.0000 & 0.0000 & 0.0000 \\
\hline $\begin{array}{l}\text { C } \\
\text { D }\end{array}$ & $\begin{array}{l}0.0000 \\
0.0000\end{array}$ & 0.0000 & 0.0000 & 0.0000 & 0.0000 & 0.0000 & 0.0000 & 0.0000 & 0.0000 & $\begin{array}{l}0.0000 \\
0.010\end{array}$ & 0.0000 & 0.0000 \\
\hline E & $\begin{array}{l}0.0000 \\
0.0000\end{array}$ & $\begin{array}{l}0.0000 \\
0.0000\end{array}$ & $\begin{array}{l}0.0000 \\
0.0000\end{array}$ & $\begin{array}{l}0.0000 \\
0.0345\end{array}$ & $\begin{array}{l}0.0000 \\
0.0000\end{array}$ & $\begin{array}{l}0.0172 \\
0.0172\end{array}$ & $\begin{array}{l}0.0000 \\
0.0167\end{array}$ & $\begin{array}{l}0.00000 \\
0.0000\end{array}$ & $\begin{array}{l}0.0000 \\
0.0000\end{array}$ & $\begin{array}{l}0.0192 \\
0.0000\end{array}$ & $\begin{array}{l}0.00000 \\
0.0000\end{array}$ & 0.0000 \\
\hline F & 0.0500 & 0.0000 & 0.0000 & 0.0000 & 0.0000 & 0.0000 & 0.0000 & 0.0000 & 0.0000 & 0.0769 & 0.0208 & $\begin{array}{l}0.00000 \\
0.0000\end{array}$ \\
\hline G & 0.0833 & 0.0833 & 0.0741 & 0.1552 & 0.0357 & 0.0862 & 0.1500 & 0.1389 & 0.0893 & 0.1923 & 0.0625 & 0.1250 \\
\hline $\mathrm{H}$ & 0.3000 & 0.3500 & 0.2963 & 0.2931 & 0.3214 & 0.2931 & 03167 & 0.5278 & 0.3214 & 0.2885 & 0.4375 & 0.4583 \\
\hline I & 0.4833 & 0.4333 & 0.4074 & 0.3276 & 0.5000 & 0.3793 & 0.4000 & 0.2500 & 0.2143 & 0.3077 & 0.3542 & 0.3333 \\
\hline $\mathrm{J}_{\mathrm{K}}$ & $\begin{array}{l}0.0667 \\
0.0167\end{array}$ & 0.0500 & 0.0556 & 0.1207 & 0.0893 & 0.1207 & 0.0333 & 0.0000 & 0.3214 & 0.0192 & 0.1042 & 0.0417 \\
\hline $\begin{array}{l}\mathrm{K} \\
\mathrm{L}\end{array}$ & $\begin{array}{l}0.0167 \\
0.0000\end{array}$ & $\begin{array}{l}0.0833 \\
0.0000\end{array}$ & $\begin{array}{l}0.1111 \\
0.0000\end{array}$ & $\begin{array}{l}0.0172 \\
0.0172\end{array}$ & 0.0357 & $\begin{array}{l}0.0690 \\
0.0772\end{array}$ & $\begin{array}{l}0.0667 \\
0.000\end{array}$ & $\begin{array}{l}0.0000 \\
0.0000\end{array}$ & $\begin{array}{l}0.0636 \\
0.0000\end{array}$ & $\begin{array}{l}0.0192 \\
00000\end{array}$ & 0.0208 & 0.0208 \\
\hline $\mathrm{M}$ & 0.0000 & 0.0000 & 0.0185 & 0.0345 & $\begin{array}{l}0.00000 \\
0.0000\end{array}$ & $\begin{array}{l}0.0172 \\
0.0000\end{array}$ & $\begin{array}{l}0.0000 \\
0.0000\end{array}$ & $\begin{array}{l}0.0000 \\
0.0000\end{array}$ & $\begin{array}{l}0.0000 \\
0.0000\end{array}$ & $\begin{array}{l}0.0000 \\
0.0000\end{array}$ & $\begin{array}{l}0.0000 \\
0.0000\end{array}$ & 0.0000 \\
\hline $\mathrm{N}$ & 0.0000 & 0.0000 & 0.0000 & 0.0000 & 0.0000 & 0.0000 & 0.0000 & 0.0000 & 0 & $\begin{array}{l}0.0000 \\
0.0000\end{array}$ & $\begin{array}{l}0.0000 \\
0.0000\end{array}$ & $\begin{array}{l}0.00000 \\
0.0000\end{array}$ \\
\hline$H_{\text {exp }}$ & 0.6734 & 0.6847 & 0.7372 & 0.7786 & 0.6474 & 0.7556 & 0.7232 & 0.6540 & 0.7500 & 0.7873 & 0.68717 & $\begin{array}{l}0.00070 \\
0.672\end{array}$ \\
\hline$H_{\text {ots }}$ & 0.4000 & 0.4333 & 0.8148 & 0.6897 & 0.6786 & 0.6897 & 0.6667 & 0.5556 & 0.6786 & 0.6154 & 0.7083 & $\begin{array}{l}0.6-146 \\
0.9167\end{array}$ \\
\hline & 0.410 & 0.371 & -0.107 & 0.116 & -0.049 & 0.089 & 0.079 & 0.154 & 0.097 & & -0.040 & -0369 \\
\hline HWE & $* * *$ & NS & NS & NS & NS & NS & NS & NS & NS & NS & NS & ** \\
\hline \multicolumn{13}{|c|}{$A m 2 B 3 \cdot 1$ locus } \\
\hline${ }^{n}$ & & & & & & 30 & 30 & 22 & & & & \\
\hline $\mathrm{A}$ & 0.0333 & 0.0833 & 0.0333 & 0.1000 & 0.1034 & 0.0833 & 0.0833 & 0.1364 & 0.0667 & 0.0517 & 0.0345 & 0.0185 \\
\hline B & 0.6000 & 0.6500 & 0.7333 & 0.5500 & 0.6897 & 0.6000 & 05833 & 0.6136 & 0.6667 & 0.7414 & 0.0517 & 0.3889 \\
\hline C & 0.3500 & 0.1833 & 0.2167 & 0.2500 & 0.1724 & 0.2833 & 0.2333 & 0.2045 & 0.1833 & 0.1724 & 0.8621 & 0.5370 \\
\hline $\mathrm{D}$ & 0.0167 & 0.0833 & 0.0167 & 0.1000 & 0.0345 & 0.0333 & 0.1000 & 0.0455 & 0.0833 & 0.0345 & 0.0517 & 0.0556 \\
\hline$H_{\text {exp }}$ & 0.5249 & 0.5390 & $\begin{array}{l}0.4209 \\
0.267\end{array}$ & 0.6254 & 0.4912 & 0.5610 & 05983 & 0.5740 & 0.5192 & 0.4241 & 0.2547 & 0.5674 \\
\hline $\begin{array}{l}H_{\text {ots }} \\
f\end{array}$ & $\begin{array}{c}0.6667 \\
0776\end{array}$ & $\begin{array}{l}0.6000 \\
0.115\end{array}$ & $\begin{array}{l}0.3667 \\
0.13\end{array}$ & 0.6000 & 0.5517 & $\begin{array}{l}0.4667 \\
0.17\end{array}$ & 05667 & 0.5909 & 0.4000 & 0.3793 & 0.2759 & 0.4815 \\
\hline HWE & $\begin{array}{l}-0.276 \\
\mathrm{NS}\end{array}$ & $\begin{array}{l}-0.115 \\
\text { NS }\end{array}$ & $\begin{array}{l}0.131 \\
\text { NS }\end{array}$ & $\begin{array}{l}0.040 \\
\mathrm{NS}\end{array}$ & $\begin{array}{l}-0.126 \\
\text { NS }\end{array}$ & $\begin{array}{l}0.171 \\
\text { NS }\end{array}$ & $\begin{array}{l}0.054 \\
\text { NS }\end{array}$ & $\begin{array}{l}-0.030 \\
\mathrm{NS}\end{array}$ & $\begin{array}{l}0.233 \\
\mathrm{NS}\end{array}$ & $\begin{array}{l}0.107 \\
\text { NS }\end{array}$ & $\begin{array}{l}-0.085 \\
\mathrm{NS}\end{array}$ & $\begin{array}{l}\text {.0.154 } \\
\text { NS }\end{array}$ \\
\hline \multicolumn{13}{|c|}{ locus } \\
\hline$n$ & & & & 30 & & 30 & 30 & 23 & 30 & & & \\
\hline A & 0.0000 & 0.0000 & 0.0000 & 0.0167 & 0.0000 & 0.0000 & 0.0000 & 0.0000 & 0.0000 & 0.0000 & 0.0172 & 0.0000 \\
\hline B & 0.9000 & 0.8833 & 0.8000 & 0.8500 & 0.8793 & 0.9333 & 08167 & 0.7826 & 0.5500 & 0.6034 & 0.4655 & 0.6111 \\
\hline & $\begin{array}{l}0.1000 \\
0.183\end{array}$ & 0.1167 & 0.2000 & $\begin{array}{l}0.1333 \\
0.023\end{array}$ & 0.1207 & $\begin{array}{l}0.0667 \\
0.106\end{array}$ & $\begin{array}{l}0.1833 \\
0.3045\end{array}$ & $\begin{array}{l}0.2174 \\
0.3478\end{array}$ & 0.4500 & 0.3966 & 0.5172 & 0.3889 \\
\hline $\begin{array}{l}H_{\text {exp }} \\
H \\
H\end{array}$ & 0.1831 & $\begin{array}{l}0.2096 \\
0 \times 333\end{array}$ & 0.3254 & 0.2638 & $\begin{array}{l}0.2160 \\
0.2414\end{array}$ & $\begin{array}{l}0.1266 \\
0.1133\end{array}$ & $\begin{array}{l}03045 \\
0367\end{array}$ & $\begin{array}{l}0.3478 \\
0.3478\end{array}$ & $\begin{array}{l}0.5034 \\
0.56654\end{array}$ & 0.4870 & $\begin{array}{l}0.5245 \\
0.5557\end{array}$ & 0.4843 \\
\hline & $\begin{array}{l}0.20000 \\
-0.094\end{array}$ & $\begin{array}{c}0.2333 \\
-0.115\end{array}$ & $\begin{array}{c}0.4000 \\
-0234\end{array}$ & $\begin{array}{l}0.3000 \\
-0.140\end{array}$ & $\begin{array}{l}0.2414 \\
-0.124\end{array}$ & $\begin{array}{l}0.1333 \\
-0.055\end{array}$ & $\begin{array}{l}03667 \\
-0208\end{array}$ & $\begin{array}{l}0.3478 \\
-0.0000\end{array}$ & $\begin{array}{l}0.5667 \\
-0.128\end{array}$ & $\begin{array}{l}0.5172 \\
-0.0633\end{array}$ & $\begin{array}{l}0.5517 \\
-0.053\end{array}$ & 0.4815 \\
\hline HWE & & NS & & NS & NS & NS & NS & NS & NS & NS & NS & NS \\
\hline
\end{tabular}




\begin{tabular}{|c|c|c|c|c|c|c|c|c|c|c|c|c|c|}
\hline $\begin{array}{l}13 \\
\text { Pertuis } \\
0+\end{array}$ & Antioche & $\begin{array}{l}14 \\
\text { Pertuis } \\
1+\end{array}$ & Antioche & $\begin{array}{l}15 \\
\text { Gironde } \\
\text { Ad. }\end{array}$ & $\begin{array}{l}16 \\
\text { Gironde } \\
0+\end{array}$ & $\begin{array}{l}17 \\
\text { Gironde Ad. La Cou- } \\
\text { bre }\end{array}$ & $\begin{array}{l}18 \\
\text { Gironde Ad. Hour- } \\
\text { tin }\end{array}$ & $\begin{array}{l}19 \\
\text { Adour }\end{array}$ & $\begin{array}{l}20 \\
\text { Portugal }\end{array}$ & $\begin{array}{l}21 \\
\text { Hérault }\end{array}$ & $\begin{array}{l}22 \\
\text { Rhône }\end{array}$ & $\begin{array}{l}23 \\
\text { Adriatic }\end{array}$ & $\begin{array}{l}24 \\
\text { Aegean } \\
\text { Sea }\end{array}$ \\
\hline $\begin{array}{l}\text { Multilocus } \\
f \quad 0.084 \\
\text { HWE NS }\end{array}$ & & $\begin{array}{l}0.118 \\
\text { NS }\end{array}$ & & $\begin{array}{l}-0.067 \\
\text { NS }\end{array}$ & $\begin{array}{l}0.048 \\
\text { NS }\end{array}$ & $\begin{array}{l}-0.088 \\
\mathrm{NS}\end{array}$ & $\begin{array}{l}0.108 \\
\text { NS }\end{array}$ & $\begin{array}{l}0.016 \\
\text { NS }\end{array}$ & $\begin{array}{l}0.053 \\
\mathrm{NS}\end{array}$ & $\begin{array}{l}0.073 \\
\text { NS }\end{array}$ & $\begin{array}{l}0.112 \\
\text { NS }\end{array}$ & $\begin{array}{l}-0.052 \\
\mathrm{NS}\end{array}$ & $\begin{array}{l}-0.091 \\
\mathrm{NS}\end{array}$ \\
\hline
\end{tabular}

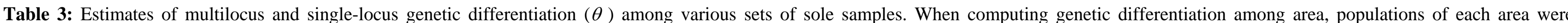
previously pooled.

\begin{tabular}{|c|c|c|c|c|}
\hline & Multilocus & $A m 2 b 1$ & $A m 2 b 2$ & $M T$ \\
\hline All populations & $0.043^{* *}$ & $0.061^{* *}$ & $0.075^{* *}$ & 0.015 \\
\hline Atlantic & 0.009 & 0.002 & 0.010 & 0.014 \\
\hline Mediterranean & $0.176^{* * *}$ & $0.313^{* * *}$ & -0.001 & 0.031 \\
\hline Atlantic vs Mediterranean & $0.068^{* * *}$ & $0.211^{* * *}$ & $0.057 * *$ & 0.002 \\
\hline Atlantic vs Western Mediterranean only & $0.049^{* *}$ & 0.006 & $0.198^{* * *}$ & 0.011 \\
\hline (Atlantic + Western Mediterranean) vs Eastern Mediterranean & $0.150^{* * *}$ & $0.272 * * *$ & $0.200^{* * *}$ & 0.009 \\
\hline Western Mediterranean vs Eastern Mediterranean & $0.135 * * *$ & $0.354^{* * * *}$ & -0.006 & 0.018 \\
\hline
\end{tabular}

Western Mediterranean vs Eastern Mediterranean $\quad 0.135^{* * *} \quad 0.354^{* * *}$

** $P<0.01 ; * * * P<0.001$ 


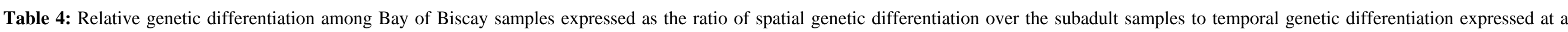
single site. *: $P<0.05$; - : no data because of negative $\theta$ estimates among temporarily replicated samples.

\begin{tabular}{|c|c|c|c|c|}
\hline & $\begin{array}{l}\theta \text { among Bay of } \\
\text { Biscay subadult } \\
\text { samples }(n=9)\end{array}$ & & $\begin{array}{l}\theta \text { among } \\
\text { replicated } \\
\text { samples at a } \\
\text { single site }\end{array}$ & $\begin{array}{l}\text { Percentage of variation } \\
\text { of } \theta \text { over time at a } \\
\text { single site relative } \\
\text { to } \theta \text { across Bay of Biscay's } \\
\text { subadult samples }\end{array}$ \\
\hline \multirow{5}{*}{ Multilocus } & \multirow{5}{*}{0.00836} & Vilaine $(n=3)$ & 0.00508 & 60.76 \\
\hline & & Loire $(n=3)$ & 0.00653 & 78.11 \\
\hline & & Pertuis Breton $(n=2)$ & -0.00135 & \\
\hline & & Pertuis d'Antioche $(n=3)$ & 0.00847 & 101.32 \\
\hline & & Gironde $(n=2)$ & 0.00889 & 106.34 \\
\hline \multirow[t]{5}{*}{$A m 2 b 3-I$} & \multirow[t]{5}{*}{0.00468} & Vilaine $(n=3)$ & 0.01168 & 249.57 \\
\hline & & Loire $(n=3)$ & 0.00687 & 146.80 \\
\hline & & Pertuis Breton $(n=2)$ & 0.00135 & 28.85 \\
\hline & & Pertuis d'Antioche $(n=3)$ & 0.00829 & 177.14 \\
\hline & & Gironde $(n=2)$ & 0.02539 & 542.52 \\
\hline \multirow{5}{*}{$A m 2 b 3 \cdot 2$} & \multirow[t]{5}{*}{$0.01498^{*}$} & Vilaine $(n=3)$ & 0.00167 & 11.15 \\
\hline & & Loire $(n=3)$ & -0.01443 & \\
\hline & & Pertuis Breton $(n=2)$ & -0.00377 & \\
\hline & & Pertuis d'Antioche $(n=3)$ & $0.06342^{*}$ & 423.36 \\
\hline & & Gironde $(n=2)$ & -0.00118 & \\
\hline \multirow{5}{*}{$M T$} & \multirow{5}{*}{0.00810} & Vilaine $(n=3)$ & 0.00347 & 42.84 \\
\hline & & Loire $(n=3)$ & 0.01385 & 170.99 \\
\hline & & Pertuis Breton $(n=2)$ & -0.00223 & - \\
\hline & & Pertuis d'Antioche $(n=3)$ & -0.00706 & \\
\hline & & Gironde $(n=2)$ & 0.00110 & 13.58 \\
\hline
\end{tabular}

